ELORE (ISSN 1456-3010), vol. $12-2 / 2005$.

Julkaisija: Suomen Kansantietouden Tutkijain Seura ry. Taitto: Jukka Talve ja Outi Fingerroos. [http://cc.joensuu.fi/ loristi/2_05/pau2_05.pdf]

\title{
AjanKohtaista:
}

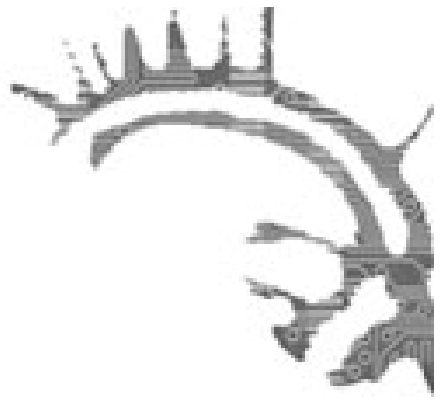

\section{SUOMEN ETNOMUSIKOLOGINEN SEURA RY}

\author{
Elina Paukkunen
}

Suomen etnomusikologinen seura ry (SES) on toiminut jo 30 vuotta etnomusikologisen tutkimuksen edistäjänä Suomessa. Vaikka seura on luonteeltaan tieteellinen yhdistys, jäseninä on musiikintutkimuksen ja lähitieteiden tutkijoiden ja opiskelijoiden lisäksi myös muita musiikin ammattilaisia ja harrastajia. Etnomusikologisen seuran toimintamuotoja ovat sen julkaisut, Etnomusikologian vuosikirja, Musiikin sunnta -lehti ja julkaisusarja, sekä erilaiset seminaarit ja kokoukset.

Etnomusikologian vuosikirja on vuosittain ilmestyvä tieteellinen, vertaisarviointikäytäntöä noudattava artikkelikokoelma. Musiikin suunta on etnomusikologisia tutkimusaiheita ja menetelmiä populaarilla tavalla käsittelevä aikakauslehti, joka ilmestyy neljä kertaa vuodessa. Molemmissa julkaisuissa, kuten seuran toiminnassa ylipäätäänkin, etnomusikologia ymmärretään väljästi kulttuurisensitiiviseksi asenteeksi musiikintutkimuksessa, ja siten artikkelit voivat edustaa monenlaisia tutkimusperinteitä ja tarkastella mitä tahansa musiikkia.

Suomen etnomusikologisen seuran julkaisusarjassa julkaistaan laajempia tieteellisiä esityksiä, erityisesti väitöskirjoja. Tähän mennessä julkaisusarjassa on ilmestynyt kymmenen teosta, joista viimeisin on Ahti Nikkosen väitöskirja Ravintolamuusikon ammatin nousu ja tubo (2004). Tavoitteena on julkaista jatkossa vuosittain yksi tai kaksi uutta suomalaista etnomusikologista tutkimusta. Seura tukee julkaisusarjaan hyväksyttyjä kirjoja taloudellisesti ja huolehtii niiden levityksestä.

Etnomusikologinen seura on vuodesta 1998 lähtien järjestänyt yhteistyössä Suomen musiikkitieteellisen seuran kanssa vuosittain musiikintutkimuksen symposiumin, joka kokoaa yhteen suomalaisia musiikintutkijoita ja johon kutsutaan ajankohtaisia ulkomaisia vieraita. Etnomusikologinen ja musiikkitieteellinen seura julkaisevat myös yhteistä Musetti-jäsentiedotetta, johon kootaan kaksi kertaa vuodessa tietoja seurojen toiminnasta sekä musiikintutkimukseen liittyvistä tapahtumista.

Toiminnan organisoimiseksi pidetään säännöllisesti kaksi vuosikokousta: marras-joulukuussa valitaan seuraavan vuoden hallitus ja helmi-maaliskuussa tehdään tilinpäätös. Molemmissa kokouksissa keskustellaan myös tulevasta toiminnasta. Näiden sääntömääräisten kokousten lisäksi järjestetään niin sanottuja neljännesvuosikokouksia, useimmiten yhteistyössä musiikkitieteen tai etnomusikolo- 
gian oppiaineiden kanssa esimerkiksi seminaarien tai vierailuluentojen yhteydessä. Kokouksia pyritään järjestämään vaihtelevasti eri paikkakunnilla.

Etnomusikologisen seuran toiminnan yleisenä tavoitteena voi pitää valtakunnallisen keskustelun lisäämistä musiikintutkimuksessa. Seura onkin tunnettu keskustelevana ja kriittisenä yhteisönä, jossa niin seuran kuin itse etnomusikologiankin mielekkyys on toistuvasti kyseenalaistettu. Tieteenalan kannalta tämä jatkuva itsereflektio on kuitenkin ollut hedelmällistä, sillä seuran parista on vuosien varrella lähtenyt liikkeelle monenlaisia suomalaista musiikintutkimusta ja jopa koko musiikkielämää uudistaneita ajatuksia.

Etnomusikologisen seuran toiminnan alkuvuosina tärkeänä tavoitteena pidettiin etnomusikologisen tutkimuksen edistämisen lisäksi maailman musiikkien tunnetuksi tekemistä. Tämän tehtävän hoitaminen on siirtynyt osittain Maailman musiikin keskukselle, jota SES oli perustamassa ja jonka kanssa edelleen tehdään yhteistyötä. Seura pyrkii tekemään yhteistyötä myös muiden kotimaisten lähialoja edustavien seurojen ja yhdistysten kanssa, ja esimerkiksi seuran 30-vuotisseminaari marraskuussa 2004 järjestettiin yhdessä Suomalaisen Kirjallisuuden Seuran kanssa. Lisäksi seura pitää yhteyttä kansainvälisiin kansan- ja populaarimusiikin tutkimuksen järjestöihin.

Etnomusikologisen seuran jäseneksi liittymisen ensisijainen edellytys on jäsenmaksun maksaminen. Jäsenmaksu on tänä vuonna 27 euroa, opiskelijoille ja työttömille 13,50 euroa, ja se sisältää Etnomusikologian vuosikirjan ja Musïkin suunnan vuosikerran. Jäsenillä on mahdollisuus vaikuttaa seuran toimintaan osallistumalla vuosikokouksiin ja ottamalla yhteyttä hallituksen jäseniin.

Ajankohtaisista asioista tiedotetaan sähköpostilistalla, jonka liittymisohjeet näkyvät edellä mainitussa osoitteessa. Jäseneksi liittymisen ohjeet saa seuran sihteeriltä.

Lisätietoja seuran toiminnasta ja julkaisuista saa osoitteesta http://www.helsinki.fi/ music/ses/.

Puheenjohtaja:

Vesa Kurkela (Sibelius-Akatemia), vkurkela(at)siba.fi

Varapuheenjohtaja:

Antti-Ville Kärjä (Turun yliopisto)

avkarj(at)utu.fi

Sihteeri:

Päivi Juvonen (Helsingin yliopisto), paivi.juvonen(at)helsinki.fi

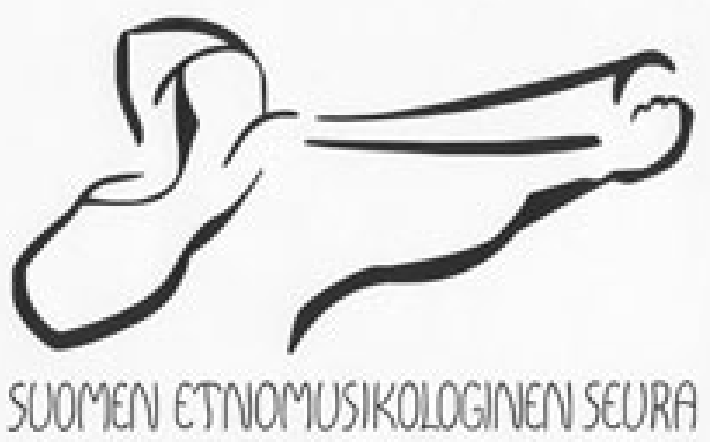

FM Elina Paukkunen on helsinkiläinen etnomusikologi, seuran hallituksen jäsen ja Musiikin suunta -lehden toinen päätoimittaja. 